\title{
Calcium- and iron-chelating activity and functional properties of salmon by-product proteolysate
}

\section{Tam Dinh Le Vo ( $\nabla$ vdlt@hcmut.edu.vn )}

Ho Chi Minh City University of Technology: Truong Dai hoc Bach khoa Dai hoc Quoc gia Thanh pho Ho Chi Minh https://orcid.org/0000-0001-8295-1165

\section{Bao Chi Vo}

Division of Food Technology, Faculty of Chemical Engineering, Ho Chi Minh City University of Technology - Vietnam National University-Ho Chi Minh, 268 Ly Thuong Kiet street, ward 14, district 10, Ho Chi Minh city, Vietnam

\section{Linh Thi Thuy Tran}

Division of Food Technology, Faculty of Chemical Engineering, Ho Chi Minh City University of Technology - Vietnam National University-Ho Chi Minh, 268 Ly Thuong Kiet street, ward 14, district 10, Ho Chi Minh city, Vietnam

\section{Linh Vy Truc Nguyen}

Division of Food Technology, Faculty of Chemical Engineering, Ho Chi Minh City University of Technology - Vietnam National University-Ho Chi Minh, 268 Ly Thuong Kiet street, ward 14, district 10, Ho Chi Minh city, Vietnam

\section{Phuong Thanh Nguyen}

Division of Food Technology, Faculty of Chemical Engineering, Ho Chi Minh City University of Technology - Vietnam National University-Ho Chi Minh, 268 Ly Thuong Kiet street, ward 14, district 10, Ho Chi Minh city, Vietnam

\section{Duy Thanh Le}

Division of Food Technology, Faculty of Chemical Engineering, Ho Chi Minh City University of Technology - Vietnam National University-Ho Chi Minh, 268 Ly Thuong Kiet street, ward 14, district 10, Ho Chi Minh city, Vietnam

\section{Minh Cao Tran}

Division of Food Technology, Faculty of Chemical Engineering, Ho Chi Minh City University of Technology - Vietnam National University-Ho Chi Minh, 268 Ly Thuong Kiet street, ward 14, district 10, Ho Chi Minh city, Vietnam

\section{Phong Thanh Bui}

Division of Food Technology, Faculty of Chemical Engineering, Ho Chi Minh City University of Technology - Vietnam National University-Ho Chi Minh, 268 Ly Thuong Kiet street, ward 14, district 10, Ho Chi Minh city, Vietnam 
Research

Keywords: salmon by-product, calcium-binding capacity, iron-binding capacity, proteolysate, peptide fraction, functional property

Posted Date: December 7th, 2020

DOl: https://doi.org/10.21203/rs.3.rs-121864/v1

License: (c) (i) This work is licensed under a Creative Commons Attribution 4.0 International License. Read Full License 


\section{Abstract}

In this study, calcium- and iron-binding proteolysate were generated using salmon by-product. It was shown by the result that under the hydrolysis condition including Neutrase, $45^{\circ} \mathrm{C}, \mathrm{pH} 7, \mathrm{E}: \mathrm{S}$ proportion of $70 \mathrm{U} / \mathrm{g}$ protein and $8 \mathrm{~h}$ of hydrolysis, the proteolysate reached the peaks of $\mathrm{CaBC}$ and IBC of $220.8 \pm 3.1$ $\mathrm{mgCa}{ }^{2+} / \mathrm{g}$ protein and $232.3 \pm 4.7 \mu \mathrm{gFe} \mathrm{e}^{2+} / \mathrm{g}$ protein, respectively. In $\mathrm{pH}$ from $3-8$, after heating at $63^{\circ} \mathrm{C}$ for 30 min or $93{ }^{\circ} \mathrm{C}$ for $30 \mathrm{~s}$ (i) its solubility was over $85 \%$ and remained over $65 \%$; (ii) FCs and FSs were 1.4-4.7 and 1.8-12.8 times lower than those of albumin; (iii) EAls and ESIs were 1.1-2.7 and 4.1-11.1 folds less than those of sodium caseinate, respectively; (iv) $\mathrm{WHC}$ and $\mathrm{OHC}$ reached $2.00 \pm 0.09 \mathrm{~mL}$ water/g proteolysate powder and $6.47 \pm 0.25 \mathrm{~mL}$ oil/g proteolysate powder, respectively. Moreover, the < $1 \mathrm{kDa}$ fraction displayed the highest $\mathrm{CaBC}$ and IBC. In conclusion, the proteolysate/peptides could be utilized in either easing micronutrient deficiency or preparation of functional peptides.

\section{Introduction}

Of all the bivalent metal ions, one of the essential minerals for human body is calcium, taking part in nerve conduction, muscle contraction, mitosis, blood coagulation, and structural support of the skeleton (Liu F-R et al. 2013). Moreover, it also plays an important role in several physiological functions including cell proliferation, responses to hormones and the release of neurotransmitters (Guo $L$ et al. 2014). Rickets, osteoporosis, hypertension, obesity and kidney stone were related to calcium deficiency (Lee SH and Song KB 2009a), all of which could be prevented by calcium-fortified products or calcium supplements in forms of inorganic calcium, organic calcium, amino acid-calcium complexes or calcium-binding peptides. However, absorption and bioavailability of calcium could be lowered as during gastrointestinal digestion, inorganic calcium supplements such as calcium carbonate or calcium chloride produce calcium phosphate precipitate, causing intestinal side effects such as flatulence and bloating (Bronner $F$ and Pansu D 1999, Wang L et al. 2018). As for organic calcium such as calcium lactate and calcium gluconate, in clinical trial, low therapeutic effects were observed due to low bioavailability and low proportion of calcium (Wang L et al. 2018). Because of their high cost, propensity to cause unfavorable color and fat oxidation, amino acid-calcium complexes were gradually replaced (Guo $L$ et al. 2014). Throughout the changes of $\mathrm{pH}$ during digestion, with the capability of remaining a soluble form of calcium, calcium bioavailability could be enhanced utilizing calcium-binding peptides as a potential alternative (Liu F-R et al. 2013). Additionally, there is no denying that the advantages of the absorption of small peptides are little energy consumption, accelerating transport speed, and carriers not being easy to saturate (Sun $\mathrm{N}$ et al. 2016). With the ability to prevent the precipitation of calcium during digestion, CPP increases the amount of soluble calcium available for absorption across the mucosa, hence it can be used as a potential calcium supplement (Jung WK and Kim SK 2007). Despite the relatively high price and the complexity of production of CPP, recently, the search for alternative calcium supplements has attracted many researchers. It has been proven that aquatic products and their by-products are great protein sources for the production of calcium-binding peptides, which were found in the proteolysate of 
Antarctic krill (Hou H et al. 2018), Pacific cod bone (Peng Z et al. 2017), cuticle of the crayfish (Inoue H et al. 2004), tilapia (Charoenphun N et al. 2013) and hoki frame (Jung WK and Kim SK 2007).

Another one of the most essential elements required for energy production, oxygen and electron transport, mitochondrial respiration and DNA synthesis is iron (Hershko C 2005). Iron deficiency could result in anemia, poor cognitive development and increased maternal mortality, all of which could be averted by fortifying iron into food in forms of iron salt, elemental iron and iron-binding peptides (Guo L et al. 2013, Ying $L$ et al. 2017). It was reported from Gaucheron $F(2000)$ that the drawbacks of iron salt and elemental iron that narrowed their applications were low bioavailability, poor taste and insolubility. In addition, during peptic digestion, the ferrous ions must be first reduced by the enzyme ferric reductase locating on the brush border of the enteric cells before being absorbed as they are quickly oxidized to the insoluble ferric form (Eckert $E$ et al. 2016). Moreover, ferrous sulfate was indicated from the study of Caetano-Silva ME et al. (2018) to promote the formation of hydroxyl radicals, starting the peroxidation of lipids from biologic membranes, enzyme inactivation, and DNA damage. In contrast, although ironbinding peptides were released at higher $\mathrm{pH}$ of duodenum, they had the ability to form a stable soluble complex with ferrous ion and remain the complex under acid condition in the stomach, improving iron absorption, stability and bioavailability (Bouhallab S et al. 2002, Lee SH and Song KB 2009b). Recently, several publications have been published on finding iron-binding peptides from various marine life forms and by-products such as shrimp by-product (Huang G et al. 2011b), Alaska pollock skin (Guo L et al. 2013), Pacific cod skin gelatin (Wu W et al. 2017), sea cucumber (Sun $N$ et al. 2017) and anchovy muscle protein (Wu H et al. 2012).

Enzymatic hydrolysis has been an effective strategy in the production of protein hydrolysate possessing functional properties including solubility, heat stability, emulsifying and foaming property, oil and water holding capacity. Proteolysate with size-varied peptides that can be applied in food enhancement could be generated from modified enzymatic proteolysis (Pacheco-Aguilar R et al. 2008), which was also considered as a means to convert wastes and by-products into more marketable and acceptable preparations, especially bioactive proteolysate or peptides from fish by-products (Souissi $\mathrm{N}$ et al. 2007).

Salmon processing industry has got rid of a colossal amount of by-products containing fins, tail, bone, remaining flesh,..., which was evaluated to be abundant in protein, bioactive components and essential nutrients that could improve human health (Chalamaiah M et al. 2012). Nevertheless, as the use of these derivatives is limited, a valuable source of protein becomes a waste. The by-product have been utilized to produce antioxidant peptides (Vo TDL et al. 2018a, Wu R et al. 2017) or proteolysates with some functional features such as emulsifying, foaming, and oil holding capacity (Gbogouri GA et al. 2004, Kristinsson HG and Rasco BA 2000). However, publications on salmon derivatives to generate calciumbinding and iron-binding proteolysate expressing functional characteristics have not been reported.

In this investigation, the proteolysate expressing the most remarkable $\mathrm{CaBC}$ and IBC was obtained by examining the effects of enzymatic hydrolysis condition comprising of hydrolysis enzyme type, temperature, $\mathrm{pH}, \mathrm{E}: \mathrm{S}$ ratio and hydrolysis time on $\mathrm{CaBC}$ and IBC of the salmon by-product proteolysate. 
The evaluations of functional properties including solubility, heat stability, emulsifying and foaming property, oil and water holding capacity $\mathrm{WHC}$ and $\mathrm{OHC}$ of the proteolysate were also carried out. Then four peptide fractions were collected and tested for their $\mathrm{CaBC}$ and IBC by performing peptide fractionation of the proteolysate using ultrafiltration centrifugal devices.

\section{Materials And Methods}

\section{Materials}

\section{Salmon by-product}

The salmon frames including bones, fins, tails and some remaining flesh attached to the frames were procured from a company in Ho Chi Minh city. The by-products were conveyed on ice to the Biochemical laboratory of Ho Chi Minh city University of Technology - Vietnam National University Ho Chi Minh city within $4 \mathrm{~h}$, separately packaged in polyethylene bags, marked and kept at $-20^{\circ} \mathrm{C}$ until used. The chemical composition of salmon by-product which contained $61.9 \pm 0.2 \%$ moisture, $44.3 \pm 0.7 \%$ crude protein, $45.4 \pm 1.1 \%$ crude lipid and $10.2 \pm 0.2 \%$ ash (on dry weight basis) was evaluated by the method of AOAC (2000).

\section{Chemicals and enzyme preparations}

Alcalase ${ }^{\circledR} 2.5 \mathrm{~L}$, Neutrase ${ }^{\circledR} 0.8 \mathrm{~L}$, Protamex ${ }^{\circledR}$ and Flavourzyme ${ }^{\circledR} 500 \mathrm{MG}$ were gained from Novozymes (Denmark) and AB enzymes (Germany). Chemicals were acquired from Sigma-Aldrich and Merck. All reagents were in analytic quality. Double-distilled water was employed in tests.

\section{Methods}

\section{Preparation of hydrolysate}

The procedure of Vo TDL et al. (2018b) with slight modification was performed to prepare the hydrolysates. The endogenous enzymes were deactivated by heating mixture of by-product and water with the ratio of $1: 10(\mathrm{w} / \mathrm{v})$ at $90^{\circ} \mathrm{C}$ for $10 \mathrm{~min}$. After hydrolysis at a predetermined time, the enzymes were deactivated by heating the hydrolysates for $10 \mathrm{~min}$ at $90^{\circ} \mathrm{C}$. The supernatant was recovered by centrifuging the hydrolysates. The protein content and $\mathrm{DH}$ of the proteolysate were measured applying the method of Lowry OH et al. (1951) and Nielsen PM et al. (2001), respectively. The collected supernatants were freeze - dried using a freeze - dryer (Alpha 1-2/Ldplus, UK) and stocked at $-20^{\circ} \mathrm{C}$ until being used.

\section{Effect of hydrolysis condition on the $\mathrm{CaBC}$, IBC and $\mathrm{DH}$ of the proteolysate}

A single factor test approach, which was carried out by one factor being altered on various levels while others being given, was performed to determine the impacts of five effective parameters consisting of 
hydrolysis enzyme type, $\mathrm{pH}$, temperature, $\mathrm{E}: \mathrm{S}$ ratio and hydrolysis time on the $\mathrm{CaBC}, \mathrm{IBC}$ and $\mathrm{DH}$ of the proteolysate.

\section{Determination of CaBC}

The same method in our previous study was employed to perform the calcium-binding test (Vo TDL et al. 2018b). After demineralization using macroporous resin (Amberlite IRC - 748I, sodium structure, Acros), hydrolysates with different concentrations up to $500 \mathrm{mg} / \mathrm{L}$ were blended with $5 \mathrm{mM} \mathrm{CaCl}_{2}$ and $20 \mathrm{mM}$ sodium phosphate support ( $\mathrm{pH} 7.8)$, which was then mixed at $22^{\circ} \mathrm{C}$ within 30 minutes. The $\mathrm{pH}$ was kept at $\mathrm{pH} 7.8$ utilizing $1 \mathrm{~N} \mathrm{HCl}$ or $1 \mathrm{~N} \mathrm{NaOH}$. The amount of calcium in supernatants was quantified utilizing ortho - cresolphtalein complexone (OCPC). The analysis was performed in triplicate and data were shown as means \pm standard deviations.

\section{Determination of IBC}

The IBC of the proteolysate in this research was estimated employing the method published in our previous study (Vo TDL et al. 2020). After using macroporous resin (Amberlite IRC-748I sodium form, Acros) for demineralization, $1 \mathrm{~mL}$ of proteolysate was added to $2.5 \mathrm{~mL}$ of acetate buffer $(0.1 \mathrm{M}, \mathrm{pH} 5)$ and $0.6 \mathrm{~mL}$ of $\mathrm{FeSO}_{4}$ solution $(0.2 \mathrm{mM})$, in order. After 30 minutes, $0.3 \mathrm{~mL}$ of Ferrozine $(5 \mathrm{mM})$ was added and the observation of the absorbance of $\mathrm{Fe}^{2+}$-Ferrozine complex was performed at $562 \mathrm{~nm}$. The IBC was calculated by the following formula:

$\operatorname{IBC}\left(\mu \mathrm{g} \mathrm{Fe} \mathrm{e}^{2+} / \mathrm{g}\right.$ protein $)=\left[\left(\mathrm{A}_{\mathrm{c}}-\mathrm{A}_{\mathrm{s}}\right) \times \mathrm{m}_{\mathrm{Fe} 2+}\right] /\left(\mathrm{A}_{\mathrm{c}} \times \mathrm{m}_{\text {protein }}\right)(1)$

Where: $A_{c}$ denotes the absorbance of the blank; $A_{s}$ is the absorbance of the sample; $m_{\mathrm{Fe} 2+}$ indicates the initial weight of $\mathrm{Fe}^{2+}, \mu \mathrm{g} ; \mathrm{m}_{\text {protein }}$ represents the weight of protein of proteolysate, $\mathrm{g}$.

\section{Determination of solubility}

The method of Li X et al. (2012) was slightly modified to evaluate the solubility of the proteolysate. $1 \mathrm{M}$ $\mathrm{HCl}$ or $\mathrm{NaOH}$ solution was used to adjust the $\mathrm{pH}$ of the mixture of hydrolysate samples $(100 \mathrm{mg})$ in $10 \mathrm{ml}$ of deionized water to $3,4,5,6,7$ and 8 . Then, prior to being centrifuged to collect the supernatant, the mixture was stirred at room temperature for $30 \mathrm{~min}$. The sample was next dissolved in $0.5 \mathrm{M} \mathrm{NaOH}$ solution, of which the total protein content was estimated using the method of Lowry OH et al. (1951). Protein solubility was calculated as follows:

Solubility $(\%)=$ Protein content in supernatant * $100 /$ Total protein content in sample (2)

\section{Determination of heat stability}

The heat stability of the proteolysate was assessed utilizing the procedure of Li X et al. (2012) with a minor variation. The $\mathrm{pH}$ of the solution consisting of $100 \mathrm{mg}$ of hydrolysate and $10 \mathrm{~mL}$ of deionized water was regulated in the range of 3 to 8 using $1 \mathrm{M} \mathrm{HCl}$ or $1 \mathrm{M} \mathrm{NaOH}$ solution. After being heated at 63 ${ }^{\circ} \mathrm{C}$ for 30 min and $93^{\circ} \mathrm{C}$ for $30 \mathrm{~s}$, the supernatant was collected by centrifugation after keeping the 
solution in iced-water for $10 \mathrm{~min}$. The heat stability of the proteolysate was expressed as its solubility after heat treatment.

\section{Determination of FC and FS}

The method of $\mathrm{Li} \mathrm{X}$ et al. (2012) with a minor variation was performed to estimate the FC of the proteolysate. The $\mathrm{FC}$ was assessed in the $\mathrm{pH}$ ranging between 3 and 8 . The collected whipped specimen by homogenizing $40 \mathrm{~mL}$ of $10 \mathrm{mg} / \mathrm{mL}$ proteolysate was instantly moved into a $100 \mathrm{~mL}$ cylinder and the total volume was recorded after $30 \mathrm{~s}$. The FC was determined by the following equation:

\section{$\mathrm{FC}(\%)=[(\mathrm{A}-\mathrm{B}) / \mathrm{B}] * 100(2)$}

Where $A$ indicates the volume of the proteolysate after being whipped $(\mathrm{mL})$; $B$ represents the volume of the proteolysate before being whipped $(\mathrm{mL})$.

The whipped sample was left at $20^{\circ} \mathrm{C}$ for $3 \mathrm{~min}$ and its volume was then monitored. The FS was evaluated via the following equation:

FS $(\%)=\left[\left(A_{t}-B\right) / B\right]^{* 100(3)}$

Where $A_{t}$ expresses the volume of the proteolysate after standing $(\mathrm{mL})$; $B$ depicts the volume of the proteolysate before being whipped $(\mathrm{mL})$.

\section{Determination of EAI and ESI}

In order to determine emulsifying property of the proteolysate, the method of Li X et al. (2012) with a minor alteration was applied. The mixture of $5 \mathrm{~mL}$ of vegetable oil and $15 \mathrm{~mL}$ of $10 \mathrm{mg}$ protein/mL hydrolysate had its $\mathrm{pH}$ varied from 3 to 8 using $0.1 \mathrm{M} \mathrm{NaOH}$ or $0.1 \mathrm{M} \mathrm{HCl}$ solution prior to being homogenized. At 0 min and 10 min after homogenization, a $50 \mu \mathrm{L}$ aliquot of the emulsion was taken from the bottom of the container. Afterwards, $4.95 \mathrm{~mL}$ of $1 \mathrm{mg} / \mathrm{mL}$ sodium dodecyl sulfate solution was added to the blend and the absorbance was determined at $500 \mathrm{~nm}$. The EAI and ESI were estimated by the equation:

EAl $\left(\mathrm{m}^{2} / \mathrm{g}\right)=2$ * $2.303 * \mathrm{~A}_{0} /(0.25$ * protein weight $(\mathrm{g}))(4)$

$\mathrm{ESI}(\min )=\mathrm{A}_{0} * \Delta \mathrm{t} / \Delta \mathrm{A}(5)$

Where $\Delta \mathrm{A}=\mathrm{A}_{0}-\mathrm{A}_{10} ; \Delta \mathrm{t}=10 \mathrm{~min} ; \mathrm{A}_{0}$ and $\mathrm{A}_{10}$ are the absorbances of the samples taken at 0 min and 10 min after homogenization, respectively.

\section{Determination of $\mathrm{OHC}$}

The procedure of Putra SNKM et al. (2018) was slightly adjusted to assess the OHC of the proteolysate. The mixture of $0.5 \mathrm{~g}$ of each sample to $10 \mathrm{~mL}$ of vegetable oil in $50 \mathrm{~mL}$ centrifugal tube was kept at temperature of $25 \pm 1^{\circ} \mathrm{C}$ (30 s of agitation was performed every $10 \mathrm{~min}$ ) for $30 \mathrm{~min}$. Afterwards, it was 
centrifuged and the volume of the supernatant was measured. The amount of oil clinging to the wall of the tube was evaluated applying the same protocol. This assay was carried out in triplicate and the $\mathrm{OHC}$ was described as the volume $(\mathrm{mL})$ of oil absorbed by $1 \mathrm{~g}$ of proteolysate.

\section{Determination of WHC}

The WHC was determined applying the centrifugation method presented by Putra SNKM et al. (2018). $0.5 \mathrm{~g}$ of sample was first rehydrated with $20 \mathrm{~mL}$ of water in each centrifuge tube then scattered with a vortex mixer for $30 \mathrm{~s}$. Next, before centrifugation, the dispersion was left at room temperature for $6 \mathrm{~h}$. Whatman No. 1 filter paper was used to filter the supernatant and its volume was accurately measured. The variance between the initial volume of distilled water added to the protein sample and the volume of the supernatant was evaluated, which was depicted as $\mathrm{mL}$ of water absorbed per $1 \mathrm{~g}$ of protein sample.

\section{Fractionation of proteolysate}

Ultrafiltration centrifugal devices of $30 \mathrm{kDa}, 10 \mathrm{kDa}, 3 \mathrm{kDa}$ and $1 \mathrm{kDa}$ (Thermo - Fisher Scientific, Pall, USA) were applied to collect four peptide fractions of $10-30 \mathrm{kDa}, 3-10 \mathrm{kDa}, 1-3 \mathrm{kDa}$, and $<1 \mathrm{kDa}$ from the proteolysate., which were then tested for their metal binding capacity.

\section{Statistical analysis}

Data were presented as means \pm standard deviations of triplicate analyses. Estimation of variance (oneway ANOVA) was run on the data, and the signification was affirmed by the Tukey method $(p<0.05)$. This assessment was fulfilled via the Statgraphics Centurion 18 software.

\section{Results And Discussion}

\section{Effect of hydrolysis condition on $\mathrm{CaBC}, \mathrm{IBC}$ and $\mathrm{DH}$ of salmon by-product proteolysate}

\section{Effect of hydrolysis enzyme type}

It can be shown in Fig. 1A that Neutrase expressed the greatest potential among Flavourzyme, Alcalase and Protamex to gain proteolysate expressing the highest CaBC and IBC of $115.3 \pm 1.98 \mathrm{mgCa}^{2+} / \mathrm{g}$ protein and $123.7 \pm 3.5 \mu \mathrm{gFe}{ }^{2+} / \mathrm{g}$ protein, respectively. Enzyme specificity plays a vital role in bioactivity of proteolysate as it remarkably impacts molecular size and the hydrophobic/hydrophilic balance of peptides in proteolysate (Kristinsson HG and Rasco BA 2000). Neutrase proteolysate has the highest DH (Fig. 1A), producing more short-chain peptides. This might be due to this protease is an endopeptidase having no specific cutting site (Yu Y et al. 2018). As for the other three enzymatic proteolysates possessing lower mineral-chelating capability, it might be because of the steric barrier of long chain peptides lowering their migration capacity to chelate target metal ions (Intarasirisawat R et al. 2012). Hence, Neutrase was implemented for further investigations. 
[Fig. 1 about here.]

\section{Effect of hydrolysis temperature}

With regards to the impact of temperature, the $\mathrm{CaBC}$ and IBC reached the peaks of $157.9 \pm 1.3 \mathrm{mgCa}{ }^{2+} / \mathrm{g}$ protein and $162.6 \pm 6.2 \mu \mathrm{gFe} \mathrm{F}^{2+} / \mathrm{g}$ protein, respectively, at $45^{\circ} \mathrm{C}$ (Fig. 1B). Temperature affects the activation energy, speed of reaction, and thermal stability of enzyme and substrate, as active site of enzyme is restricted by higher temperature, interrupting hydrolysis and affecting the bioactivity of the proteolysate (Thiansilakul $Y$ et al. 2007). At $40{ }^{\circ} \mathrm{C}$ (Fig. 1B), higher DH meant that proteolysate may contain numerous small peptides, which was revealed to be unable to form complexes with metals (Intarasirisawat R et al. 2012). Thus, hydrolysis temperature of $45^{\circ} \mathrm{C}$ was chosen for more tests.

\section{Effect of pH}

In terms of enzymatic reaction kinetics, charged amino acid residues bind to substrate at the active site of enzyme, forming a specific association that converts a substrate to a product (Shu $G$ et al. 2017). The calcium-binding capacity of the proteolysate varies as the environmental $\mathrm{pH}$ may alter structure of enzyme as well as enzyme-substrate linkage (Shu $\mathrm{G}$ et al. 2017). Figure $1 \mathrm{C}$ demonstrated that at $\mathrm{pH} 7$ the greatest $\mathrm{CaBC}$ of $204.9 \pm 2.5 \mathrm{mgCa}^{2+} / \mathrm{g}$ protein and IBC of $224.9 \pm 10.3 \mu \mathrm{gFe} \mathrm{F}^{2+} / \mathrm{g}$ protein were obtained, while at greater or lower $\mathrm{pH}$, proteolysates had lower bioactivity. This was thought to be the changed catalysis activity as a result of the successive deformation of the active site of enzyme (Thiansilakul $Y$ et al. 2007). Therefore, $\mathrm{pH} 7$ was chosen for additional experiments.

\section{Effect of E:S ratio}

It was shown in Fig. 1D that the CaBC and IBC of the salmon by-product proteolysate increased correspondingly with the $\mathrm{E}: \mathrm{S}$ ratio in the $\mathrm{E}: \mathrm{S}$ ranging from 40 to $70 \mathrm{U} / \mathrm{g}$ protein. It could be understood that the higher the E:S proportion is, the higher the proteolysis rate is. As a result, with a higher amount of freed small peptides, the generated proteolysate could achieve a greater $\mathrm{DH}$, improving bioactivity of the proteolysate. However, when the hydrolysis speed is constant, all substrates are converted to products. Therefore, the increase in E:S ratio does not affect the metal-binding capacity (Kang PY et al. 2018). An insignificant change in $\mathrm{DH}$ was shown in Fig. 1D when increasing the $\mathrm{E}: \mathrm{S}$ ratio from 70 to $80 \mathrm{U} / \mathrm{g}$ protein. Moreover, the bioactivity of proteolysate was assumed by Chen D et al. (2014) to reduce because of the damaged calcium-binding peptides caused by a greater amount of enzyme created through early steps of hydrolysis. So, the E:S ratio of $70 \mathrm{U} / \mathrm{g}$ protein was used for further analyses.

\section{Effect of hydrolysis time}

As depicted in Fig. 1E, at hydrolysis time of $8 \mathrm{~h}, \mathrm{CaBC}$ and IBC peaked at $220.8 \pm 3.1 \mathrm{mgCa}^{2+} / \mathrm{g}$ protein and $232.3 \pm 4.7 \mu \mathrm{gFe}^{2+} / \mathrm{g}$ protein, in order. Enzymatic hydrolysis generates amino acid residues expressing the capability of binding calcium ions (Liu Q et al. 2010), increasing the CaBC of the proteolysate. However, when prolonging the hydrolysis time, the proteolysate's bioactivity is lowered due to either the deeper cleavage of the enzyme on generated peptides or the decrease of the enzyme activity. 
Similar results for tilapia protein hydrolysate on the relation between hydrolysis time and the $\mathrm{CaBC}$ were observed by Charoenphun N et al. (2013). Similarly, Guo L et al. (2013) also reported the hydrolysis timeIBC profile for Alaska Pollock skin proteolysate. So, $8 \mathrm{~h}$ was selected as the hydrolysis time for additional tests.

\section{Functional properties of salmon by-product proteolysate Solubility}

One of the most essential functional features of protein and proteolysate is solubility, which has an impact on other functional properties such as emulsification and foaming capability (Putra SNKM et al. 2018). The solubility of proteolysate is enhanced by the hydrogen bonds between water and the smaller peptide fractions, which are formed by cleaving protein using enzymatic hydrolysis, with polar residues (Gbogouri GA et al. 2004). Besides, Kristinsson HG and Rasco BA (2000) reported the enhanced solubility of proteolysate thanks to the balance between hydrophilic and hydrophobic force of peptides. Moreover, the environmental $\mathrm{pH}$ affects the solubility of proteolysate by changing the charge of peptides, producing a proteolysate with the lowest solubility at isoelectric point and the greatest solubility when being charged maximally (Kristinsson HG and Rasco BA 2000). Among other functional practices including emulsions, foams and gels, the most important factor is great solubility of protein as soluble proteins assisting homogeneous dispersibility of molecules in colloidal systems, the interfacial features are improved (Ktari $\mathrm{N}$ et al. 2012). As can be seen in Fig. 2A, in the pH range from 3 to 8, salmon by-product proteolysate possessed solubility of over $85 \%$, achieving a peak of $96.97 \pm 1.51 \%$ at $\mathrm{pH} 8$, which was 1.2 times higher than that of Alcalase proteolysates from golden apple snail (Putra SNKM et al. 2018). The dissimilarity in the solvability is explained by the size, the hydrophobic-hydrophilic balance and the charge of peptides formed through enzymatic hydrolysis (Ktari $\mathrm{N}$ et al. 2012). The lowest solubility of the protelolyates obtained at $\mathrm{pH} 4$ was thought to be approximate to the isoelectric point of salmon protein. The result suggested that the salmon by-product proteolysate might be employed in food products for features enhancement.

[Fig. 2 about here.]

\section{Heat stability}

Heat treatment, as a general unit operation in food processing, can impact their functional features due to thermal sensitiveness of protein ( $\mathrm{Li} \mathrm{X}$ et al. 2012). An efficient index of the denaturation level of protein is protein solubility characterization during heat handling, aiding in controlling emulsification, foaming, extraction, and gelation processes (Zayas JF 1997). Heat durability of proteolysate was described as its solubility after thermal processing at a fixed condition. In this study, after heat treatment at $63^{\circ} \mathrm{C}$ for 30 min (over $85 \%$ in the tested $\mathrm{pH}$ range), a small change in the solubility of the proteolysate was observed, which was greater than $65 \%$ after heat handling at $93{ }^{\circ} \mathrm{C}$ for $30 \mathrm{~s}$ (Fig. 2A). The heat stability of the proteolysate was relatively lower than that of grass carp proteolysate ( $\mathrm{Li} X$ et al. 2012). It could be explained by the poorer balance between hydrophilic and hydrophobic force leading to protein 
aggregation during heat handling ( $\mathrm{Li} X$ et al. 2012). Additionally, the variance of heat stability of proteolysate is also affected by different protein sources from dissimilar fish species. Heat-stable proteins were reported by Nurdiani R et al. (2016) to be found in fishes inhabiting the water with high ambient temperature. Besides, it was published by Nourmohammadi E et al. (2017) that the increase in heat stability may be because of the hindrance to form the secondary structure by Pro, lleu and amino acids with identically charged side chains as well as the generation of internal hydrophobic bonds in protein molecules.

\section{Foaming property}

The foam formation is affected by transportation, penetration as well as rearrangement of molecules at the air-water interface (Intarasirisawat $R$ et al. 2012). Protein molecules must rapidly migrate to, unfold and reorganize at the air-water interface to express great FC (Putra SNKM et al. 2018). In addition, Li X et al. (2012) reported that with the lower solubility of proteolysate, the migration speed of protein molecules to the air/water interface was lower, reducing the FC. Besides, the pH was revealed by Naqash SY and Nazeer RA (2013) to have impacts on the FC of the proteolysate through the net charge of peptides in proteolysate. Figure $2 \mathrm{~B}$ demonstrated that at $\mathrm{pH} 3$, the $\mathrm{FC}$ of the protein hydrolysate reached a peak of $36.31 \pm 1.72 \%$, which was 1.9, 2.0 and 1.5 times higher than those of proteolysates from sole skin, squid skin and round scad, respectively ( $\mathrm{Li} Z$ et al. 2013). These variances were attributed to the amount variation of longer chain peptides created through enzymatic hydrolysis, which could generate a thicker and stronger film covering air bubbles (Intarasirisawat R et al. 2012). Furthermore, in the pH ranging from 3 to 8 , the FC values of the salmon by-product were 1.4-4.7 times lower than those of albumin solution.

As intermolecular cohesiveness as well as elasticity of the protein polymers are essential for generation of stable foams, the protein molecules are required to create intermolecular polymers that embrace air bubbles to boost the FS (Ktari N et al. 2012). The FS is quantified by the level of protein-protein interaction within the matrix correlating with the ionic repulsion of peptides (Naqash SY and Nazeer RA 2013). In this research, at pH 3 , the proteolysate exhibited the highest FS of $18.90 \pm 0.86 \%$ (Fig. 2C), which was comparable to that of pink perch muscle proteolysate (Naqash SY and Nazeer RA 2013). On the other hand, in the $\mathrm{pH}$ of 3-8, the salmon by-product exerted FS 1.9-12.8 folds lower than albumin solution did. Altogether, the salmon by-product proteolysate might be utilized in some products to enhance their foaming capacity.

\section{Emulsifying property}

The mechanism of emulsification of hydrolysate is thought to be the protective membrane, which is formed through the adsorption of peptides on the surface of freshly formed oil droplets through homogenization, block their coalescence (Gbogouri GA et al. 2004). Protein solubility also affects the emulsification via rapid migration to and adsorption at the oil-water interface of protein molecules (Kristinsson HG and Rasco BA 2000). As illustrated in Fig. 2D and Fig. 2E, while EAls of the proteolysate were 1.1-2.7 times lower than those of sodium caseinate, in the $\mathrm{pH}$ range $3-8$, the proteolysate exhibited the ESI 4.1-11.1 times higher than sodium caseinate did. At pH 8, the EAI and ESI of the proteolysate 
peaked at $52.46 \pm 0.11 \mathrm{~m}^{2} / \mathrm{g}$ and $136.97 \pm 3.85 \mathrm{~min}$, respectively, which were 1.4 and 3.8 folds higher than those of round scad proteolysate, in order (Thiansilakul Y et al. 2007). Great ESI was reported by Pacheco-Aguilar $\mathrm{R}$ et al. (2008) to be achieved at high $\mathrm{pH}$ because the negatively charged peptides at alkaline $\mathrm{pH}$ led to the orientation of the peptides at the oil-water interface. Besides, it was reported by Latorres JM et al. (2018) that as the alkaline pH created the repulsion of negative charges of peptides, emulsifying feature of proteolysate was improved, benefiting their better orientation at the oil-water interface. The emulsifying feature of fish proteolysate was also reported to be directly involved in the surface property, molecular size and hydrophobicity of peptides (Santos SDAd et al. 2011). Proteolysates possessing low $\mathrm{DH}$ often comprise of larger peptides assisting their emulsifying feature via maintaining good balance between hydrophilic and hydrophobic groups (Kristinsson HG and Rasco BA 2000). Moreover, it was revealed by Putra SNKM et al. (2018) that different amino acid compositions may result in the variation in emulsifying property of different hydrolysates. Furthermore, the emulsifying stability is improved via the combination of greatly elastic protein layers absorbed on the surfaces of oil droplets, which were created by tertiary proteins and their steric effect, generating strong and thick films around oil droplets (Intarasirisawat R et al. 2012). As a whole, the proteolysate in this study might be considered to be used in some food products to boost their emulsion feature.

\section{$\mathrm{OHC}$ and WHC}

$\mathrm{OHC}$, is a critical parameter that affects the taste of the product, which is described as the amount of oil directly bound by protein. The physical entrapment of oil is supposed to be the oil-holding mechanism of proteolysate, as the greater the bulk density of protein is, the higher the $\mathrm{OHC}$ is (Kristinsson $\mathrm{HG}$ and Rasco BA 2000). Besides, OHC of hydrolysate is also under the effect of other factors such as degree of hydrolysis, the surface hydrophobicity of peptides, and enzyme-substrate specificity (Santos SDAd et al. 2011). Proteolysates expressing high DH consisting of a large amount of small peptides with superior hydrophilicity decrease the interaction between peptide and lipid, reducing $\mathrm{OHC}$ (Cumby $\mathrm{N}$ et al. 2008). With the capacity to form hydrophobic bonds to lipid, better hydrophobic peptides express higher $\mathrm{OHC}$, increasing durability of protein-lipid complex (Zayas JF 1997). In this test, the OHC of the Neutrase proteolysate achieved $6.47 \pm 0.25 \mathrm{~mL}$ oil/g proteolysate powder, 2.8 times greater than that of the hydrolysates from Chinese sturgeon(Noman A et al. 2018). This difference was attributed to the variation in hydrophilic polar side chains of peptides in these proteolysates (Noman A et al. 2018). It was suggested from the finding that the proteolysate powder might be employed to delay phase separation as well as improve palatability and taste retention of some food products (Santos SDAd et al. 2011).

WHC describes the protein capacity of absorbing water and maintaining it against gravitational force within a protein matrix. It has an impact on the texture and integrity of food products such as frozen fish fillets or meat (Putra SNKM et al. 2018). The WHC of the salmon by-product proteolysate attained $2.00 \pm$ $0.09 \mathrm{~mL}$ water/ g proteolysate powder, which was 2.1,1.7 and 1.1 times lower than those of proteolysates from golden apple snail (Putra SNKM et al. 2018), cuttlefish muscle (Amiri ZR et al. 2016) and tilapia protein (Foh MBK et al. 2011), respectively. As for deciding the WHC of a proteolysate, Cumby $\mathrm{N}$ et al. (2008) uncovered that amino acid profile and peptide size were important parameters. Lower- 
molecular-weight peptides are often more hydrophilic, therefore they are more effective in keeping water than larger-size peptides (Cumby $\mathrm{N}$ et al. 2008). Furthermore, the amount of adsorbed water is significantly affected by the rise in concentration of polar groups encompassing carboxyl and amino groups during enzymatic hydrolysis (Putra SNKM et al. 2018). The result concluded that the salmon byproduct proteolysate might be used as a moisture-keeping agent for some food products.

\section{Determination of the $\mathrm{CaBC}$ and IBC of peptide fractions}

[Fig. 3 about here.]

It was demonstrated in Fig. 3 that the $<1 \mathrm{kDa}$ peptide fraction possessed the strongest $\mathrm{CaBC}$ and IBC of $520.38 \pm 25.75 \mathrm{mgCa}^{2+} / \mathrm{g}$ protein (1.1 times higher than that of casein phosphopeptide), $998.04 \pm 30.38$

$\mu \mathrm{gFe} \mathrm{F}^{2+} / \mathrm{g}$ protein (1.7 times lower than that of $\mathrm{Na}_{2} \mathrm{EDTA}$ ), respectively. This study was consistent with the research of Huang $\mathrm{G}$ et al. (2011a) and Vo TDL et al. (2018b) on the $<1 \mathrm{kDa}$ peptide fraction exhibiting the highest calcium affinity. The steric obstacle that decreased the capacity to migrate and chelate target metal ions of long chain peptides led to low metal-chelating activity of large peptides (Intarasirisawat R et al. 2012).

\section{Conclusions}

In conclusion, the research assessed the bioactivity of the salmon by-product protein hydrolysate considering $\mathrm{CaBC}$ and IBC. In addition to a natural mineral-chelating agent for human body, the proteolysate was discovered as an emulsifier or foaming agent for food products. This original revelation pointed out that the value of the by-product was enhanced by proteolysate with a large potential on practical scale, alongside with reducing its risk of environmental pollution. Nevertheless, further clinical studies and organoleptic evaluations on food fortification using the proteolysate are needed.

\section{Abbreviations}

CaBC: Calcium-binding capacity; CPP: Casein phosphopeptide; DH: Degree of hydrolysis; EAl: Emulsifying activity index; ESI: Emulsifying stability index; E:S: Enzyme:substrate; FC: Foaming capacity; FS: Foaming stability; IBC: Iron-binding capacity; $\mathrm{Na}_{2}$ EDTA: Disodium ethylenediaminetetraacetate; $\mathrm{OHC}$ : Oil-holding capacity; WHC: Water-holding capacity.

\section{Declarations}

\section{Acknowledgements}

Not applicable.

\section{Authors' contributions}


BCV analysed the data and drafted the manuscript. LTTT, LVTN, PTN and DTL performed the experiments. MCT processed the image and formatted the manuscript. PTB made ideas. TDLV managed the overall project, supervised the experimental work, edited and reviewed the manuscript. All authors read and approved the final manuscript.

\section{Funding}

This research is funded by Vietnam National University HoChiMinh City (VNU-HCM) under grant number C2017-20-34.

\section{Availability of data and materials}

The datasets used and/or analysed during the current study are available from the corresponding author on reasonable request.

\section{Ethics approval and consent to participate}

Not applicable.

\section{Consent for publication}

Not applicable.

\section{Competing interests}

The authors declare that they have no competing interests.

\section{References}

Amiri ZR, Safari R, Bakhshandeh T, vavsari FA (2016) Functional properties of fish protein hydrolysates from Cuttlefish (Sepia pharaonis) muscle produced by two commercial enzymes. Iran J Fish Sci 15(4):1485-1499.

AOAC (2000) AOAC: Official Methods of Analysis. The Association of Official Analytical Chemists, USA.

Bouhallab S, Cinga V, Aiät-Oukhatar N, Bureau F, Neuville D et al (2002) Influence of various phosphopeptides of caseins on iron absorption. J Agric Food Chem 50(24):7127-7130. https://doi.org/10.1021/jf025554v

Bronner F, Pansu D (1999) Nutritional aspects of calcium absorption. J Nutr 129(1):9-12.

Caetano-Silva ME, Cilla A, Bertoldo-Pacheco MT, Netto FM, Alegría A (2018) Evaluation of in vitro iron bioavailability in free form and as whey peptide-iron complexes. J Food Compost Anal. 68:95-100. https://doi.org/10.1016/j.jfca.2017.03.010 
Chalamaiah M, Kumar BD, Hemalatha R, Jyothirmayi T (2012) Fish protein hydrolysates: Proximate composition, amino acid composition, antioxidant activities and applications: A review. Food Chem 135(4):3020-3038. https://doi.org/10.1016/j.foodchem.2012.06.100

Charoenphun N, Cheirsilp B, Sirinupong N, Youravong W (2013) Calcium-binding peptides derived from tilapia (Oreochromis niloticus) protein hydrolysate. Eur Food Res Technol 236(1):57-63.

https://doi.org/10.1007/s00217-012-1860-2

Chen D, Mu X, Huang H, Nie R, Liu Z et al (2014) Isolation of a calcium-binding peptide from tilapia scale protein hydrolysate and its calcium bioavailability in rats. J Funct Foods 6:575-584.

https://doi.org/10.1016/j.jff.2013.12.001

Cumby N, Zhong Y, Naczk M, Shahidi F (2008) Antioxidant activity and water-holding capacity of canola protein hydrolysates. Food Chem 109(1):144-148. https://doi.org/10.1016/j.foodchem.2007.12.039

Eckert E, Lu L, Unsworth LD, Chen L, Xie J et al (2016) Biophysical and in vitro absorption studies of iron chelating peptide from barley proteins. J Funct Foods 25:291-301.

https://doi.org/10.1016/j.jff.2016.06.011

Foh MBK, Kamara MT, Amadou I, Foh BM, Wenshui X (2011) Chemical and physicochemical properties of tilapia (Oreochromis niloticus) fish protein hydrolysate and concentrate. Int J Biol Chem 5(1):21-36. http://dx.doi.org/10.3923/ijbc.2011.21.36

Gaucheron F (2000) Iron fortification in dairy industry. Trends Food Sci Technol 11(11):403-409. https://doi.org/10.1016/S0924-2244(01)00032-2

Gbogouri GA, Linder M, Fanni J, Parmentier M (2004) Influence of hydrolysis degree on the functional properties of salmon byproducts hydrolysates. J Food Sci 69(8):615-622.

https://doi.org/10.1111/j.1365-2621.2004.tb09909.x

Guo L, Harnedy PA, Li B, Hou H, Zhang Z et al (2014) Food protein-derived chelating peptides: Biofunctional ingredients for dietary mineral bioavailability enhancement. Trends Food Sci Tech 37(2):92105.

Guo L, Hou H, Li B, Zhang Z, Wang S et al (2013) Preparation, isolation and identification of iron-chelating peptides derived from Alaska pollock skin. Process Biochem 48(5-6):988-993.

https://doi.org/10.1016/j.procbio.2013.04.013

Hershko C (2005) Treating iron overload: The state of the art. Semin Hematol. 42(2):S2-4. https://doi.org/10.1053/j.seminhematol.2005.01.003

Hou H, Wang S, Zhu X, Li Q, Fan Y et al (2018) A novel calcium-binding peptide from Antarctic krill protein hydrolysates and identification of binding sites of calcium-peptide complex. Food Chem 243:389-395. 
Huang G, Ren L, Jiang J (2011a) Purification of a histidine-containing peptide with calcium binding activity from shrimp processing byproducts hydrolysate. Eur Food Res Technol 232(2):281-287. https://doi.org/10.1007/s00217-010-1388-2

Huang G, Ren Z, Jiang J (2011b) Separation of iron-binding peptides from shrimp processing by-products hydrolysates. Food Bioprocess Tech 4:1527-1532. https://doi.org/10.1007/s11947-010-0416-3

Inoue H, Ohira T, Ozaki N, Nagasawa H (2004) A novel calcium-binding peptide from the cuticle of the crayfish, Procambarus clarkii. Biochem Biophys Res Commun 318:649-654.

Intarasirisawat R, Benjakul S, Visessanguan W, Wu J (2012) Antioxidative and functional properties of protein hydrolysate from defatted skipjack (Katsuwonous pelamis) roe. Food Chem 135(4):3039-3048. https://doi.org/10.1016/j.foodchem.2012.06.076

Jung WK, Kim SK (2007) Calcium-binding peptide derived from pepsinolytic hydrolysates of hoki (Johnius belengerii) frame. Eur Food Res Technol 224(6):763-767. https://doi.org/10.1007/s00217-0060371-4

Kang PY, Ishak NH, Sarbon NM (2018) Optimization of enzymatic hydrolysis of shortfin scad (Decapterus macrosoma) myofibrillar protein with antioxidant effect using alcalase. Int Food Res J 25(5):1808-1817.

Kristinsson HG, Rasco BA (2000) Biochemical and functional properties of Atlantic salmon (Salmo salar) muscle proteins hydrolyzed with various alkaline proteases. J Agric Food Chem 48(3):657-666. https://doi.org/10.1021/jf990447v

Ktari N, Jridi M, Bkhairia I, Sayari N, Salah RB et al (2012) Functionalities and antioxidant properties of protein hydrolysates from muscle of zebra blenny (Salaria basilisca) obtained with different crude protease extracts. Food Res Int 49(2):747-756. https://doi.org/10.1016/j.foodres.2012.09.024

Latorres JM, Rios DG, Saggiomo G, Jr. WW, Prentice-Hernandez C (2018) Functional and antioxidant properties of protein hydrolysates obtained from white shrimp (Litopenaeus vannamei). J Food Sci Technol 55(2):721-729. https://doi.org/10.1007/s13197-017-2983-z

Lee SH, Song KB (2009a) Isolation of a calcium-binding peptide from enzymatic hydrolysates of porcine blood plasma protein. J Korean Soc Appl Bi. 52(3):290-294.

Lee SH, Song KB (2009b) Purification of an iron-binding nona-peptide from hydrolysates of porcine blood plasma protein. Process Biochem 44(3):378-381. https://doi.org/10.1016/j.procbio.2008.12.001

Li X, Luo Y, Shen H, You J (2012) Antioxidant activities and functional properties of grass carp (Ctenopharyngodon idellus) protein hydrolysates. J Sci Food Agric 92(2):292-298. https://doi.org/10.1002/jsfa.4574 
Li Z, Wang B, Chi C, Gong Y, Luo H et al (2013) Influence of average molecular weight on antioxidant and functional properties of cartilage collagen hydrolysates from Sphyrna lewini, Dasyatis akjei and Raja porosa. Food Res Int 51(1):283-293. https://doi.org/10.1016/j.foodres.2012.12.031

Liu F-R, Wang L, Wang R, Chen Z-X (2013) Calcium-binding capacity of wheat germ protein hydrolysate and characterization of peptide-calcium complex. J Agric Food Chem 61(31):7537-7544.

Liu Q, Kong B, Xiong YL, Xia X (2010) Antioxidant activity and functional properties of porcine plasma protein hydrolysate as influenced by the degree of hydrolysis. Food Chem 118(2): 403-410. https://doi.org/10.1016/j.foodchem.2009.05.013

Lowry OH, Rosebrough NJ, Farr AL, Randall RJ (1951) Protein measurement with the Folin phenol reagent. J Biol Chem 193(1):265-275.

Naqash SY, Nazeer RA (2013) Antioxidant and functional properties of protein hydrolysates from pink perch (Nemipterus japonicus) muscle. J Food Sci Technol 50(5):972-978.

https://doi.org/10.1007/s13197-011-0416-y

Nielsen PM, Petersen D, Dambmann C (2001) Improved method for determining food protein degree of hydrolysis. J Food Sci 66(5):642-646. https://doi.org/10.1111/j.1365-2621.2001.tb04614.x

Noman A, Xu Y, AL-Bukhaiti WQ, Abed SM, Ali AH et al (2018) Influence of enzymatic hydrolysis conditions on the degree of hydrolysis and functional properties of protein hydrolysate obtained from Chinese sturgeon (Acipenser sinensis) by using papain enzyme. Process Biochem 67:19-28. https://doi.org/10.1016/j.procbio.2018.01.009

Nourmohammadi E, SadeghiMahoonak A, Alami M, Ghorbani M (2017) Amino acid composition and antioxidative properties of hydrolysed pumpkin (Cucurbita pepo L.) oil cake protein. Int J Food Prop 20(12):3244-3255. https://doi.org/10.1080/10942912.2017.1283516

Nurdiani R, Dissanayake M, Street WE, Donkor ON, Singh TK et al (2016) In vitro study of selected physiological and physicochemical properties of fish protein hydrolysates from 4 Australian fish species. Int Food Res J 23(5):2029-2040.

Pacheco-Aguilar R, Mazorra-Manzano MA, Ramírez-Suárez JC (2008) Functional properties of fish protein hydrolysates from Pacific whiting (Merluccius productus) muscle produced by a commercial protease. Food Chem 109:782-789. https://doi.org/10.1016/j.foodchem.2008.01.047

Peng Z, Hou H, Zhang K, Li B (2017) Effect of calcium-binding peptide from pacific cod (Gadus macrocephalus) bone on calcium bioavailability in rats. Food Chem 221:373-378.

Putra SNKM, Ishak NH, Sarbon NM (2018) Preparation and characterization of physicochemical properties of golden apple snail (Pomacea canaliculata) protein hydrolysate as affected by different proteases. Biocatal Agric Biotechnol 13:123-128. https://doi.org/10.1016/j.bcab.2017.12.002 
Santos SDAd, Martins VG, Salas-Mellado M, Prentice C (2011) Evaluation of functional properties in protein hydrolysates from bluewing searobin (Prionotus punctatus) obtained with different microbial enzymes. Food Bioprocess Technol 4(8):1399-1406. https://doi.org/10.1007/s11947-009-0301-0

Shu G, Zhang B, Zhang Q, Wan H, Li H (2017) Effect of temperature, pH, enzyme to substrate ratio, substrate concentration and time on the antioxidative activity of hydrolysates from goat milk casein by Alcalase. Acta Universitatis Cibiniensis. Series E: Food Technology 20(2):29-38.

https://doi.org/10.1515/aucft-2016-0013

Souissi N, Bougatef A, Triki-Ellouz Y, Nasri M (2007) Biochemical and functional properties of sardinella (Sardinella aurita) by-product hydrolysates. Food Technol Biotech 45(2):187-194.

Sun N, Cui P, Jin Z, Wu H, Wang Y et al (2017) Contributions of molecular size, charge distribution, and specific amino acids to the iron-binding capacity of sea cucumber (Stichopus japonicus) ovum hydrolysates. Food Chem 230:627-636. https://doi.org/10.1016/j.foodchem.2017.03.077

Sun N, Wu H, Du M, Tang Y, Liu H et al (2016) Food protein-derived calcium chelating peptides: A review. Trends Food Sci Technol 58:140-148.

Thiansilakul Y, Benjakul S, Shahidi F (2007) Compositions, functional properties and antioxidative activity of protein hydrolysates prepared from round scad (Decapterus maruadsi). Food Chem 103(4):13851394. https://doi.org/10.1016/j.foodchem.2006.10.055

Vo TDL, Pham KT, Ha DQ (2018a) Recovery of proteolysate from salmon by-product: Investigation of antioxidant activity, optimization of hydrolysis, determination of iron-binding activity and identification of bioactive peptides. The International Journal of Engineering and Science 7(9):18-30. https://doi.org/10.9790/1813-0709041830

Vo TDL, Pham KT, Le LT, Nguyen TTH (2018b) Identification of a new calcium-binding peptide from enzymatic proteolysate of Acetes japonicus. J Food Process Pres 42(12):e13837. https://doi.org/10.1111/jfpp.13837

Vo TDL, Pham KT, Le VMV, Lam HH, Huynh ON et al (2020) Evaluation of iron-binding capacity, amino acid composition, functional properties of Acetes japonicus proteolysate and identification of ironbinding peptides. Process Biochem 91:374-386. https://doi.org/10.1016/j.procbio.2020.01.007

Wang L, Ding Y, Zhang X, Li Y, Wang R et al (2018) Isolation of a novel calcium-binding peptide from wheat germ protein hydrolysates and the prediction for its mechanism of combination. Food Chem 239:416-426.

Wu H, Liu Z, Zhao Y, Zeng M (2012) Enzymatic preparation and characterization of iron-chelating peptides from anchovy (Engraulis japonicus) muscle protein. Food Res Int 48:435-441. https://doi.org/10.1016/j.foodres.2012.04.013 
Wu R, Chen L, Liu D, Huang J, Zhang J et al (2017) Preparation of antioxidant peptides from salmon byproducts with bacterial extracellular proteases. Mar Drugs 15(4):1-19.

https://dx.doi.org/10.3390\%2Fmd15010004

Wu W, Li B, Hou H, Zhang H, Zhao X (2017) Identification of iron-chelating peptides from Pacific cod skin gelatin and the possible binding mode. J Funct Foods 35:418-427.

https://doi.org/10.1016/j.jff.2017.06.013

Ying L, Kaihua W, Xiaoguang M, Yajuan W, Tuo Z et al (2017) Separation and identification of ironchelating peptides from defatted walnut flake by NanoLC-ESI-MS/MS and De novo sequencing. Process Biochem 59B:223-228. https://doi.org/10.1016/j.procbio.2017.05.010

Yu Y, Fan F, Wu D, Yu C, Wang Z et al (2018) Antioxidant and ACE inhibitory activity of enzymatic hydrolysates from Ruditapes philippinarum. Molecules 23(5):E1189.

https://dx.doi.org/10.3390\%2Fmolecules23051189

Zayas JF (1997) Functionality of Proteins in Food. Springer, Germany.

\section{Figures}



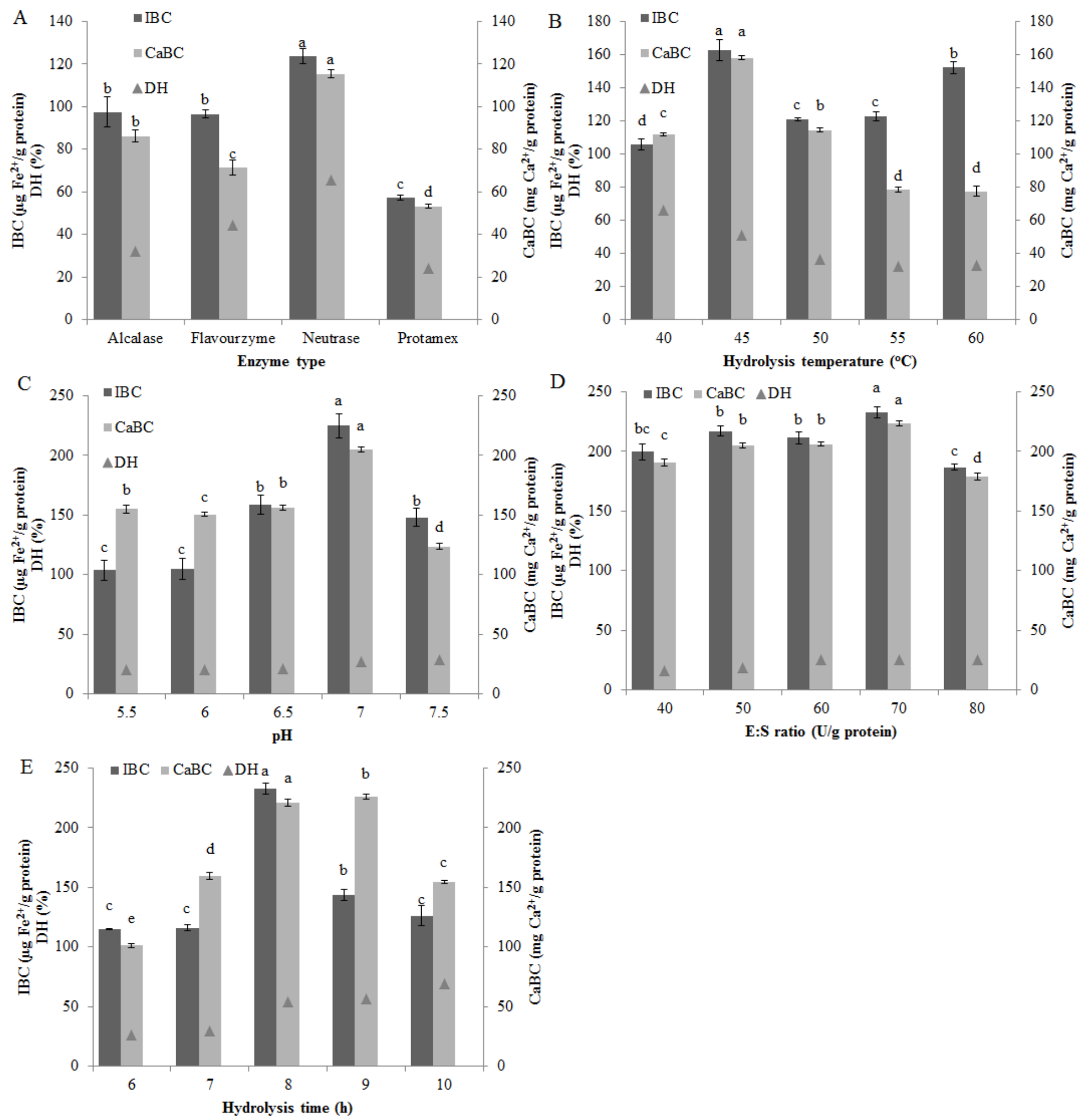

Figure 1

Effect of enzyme type (A), temperature (B), $\mathrm{pH}(\mathrm{C}), \mathrm{E}: \mathrm{S}$ ratio (D) and hydrolysis time (E) on CaBC, IBC and $\mathrm{DH}$ of the proteolysate. The same color bars with different letters indicate significant differences $(p<0.05)$ 

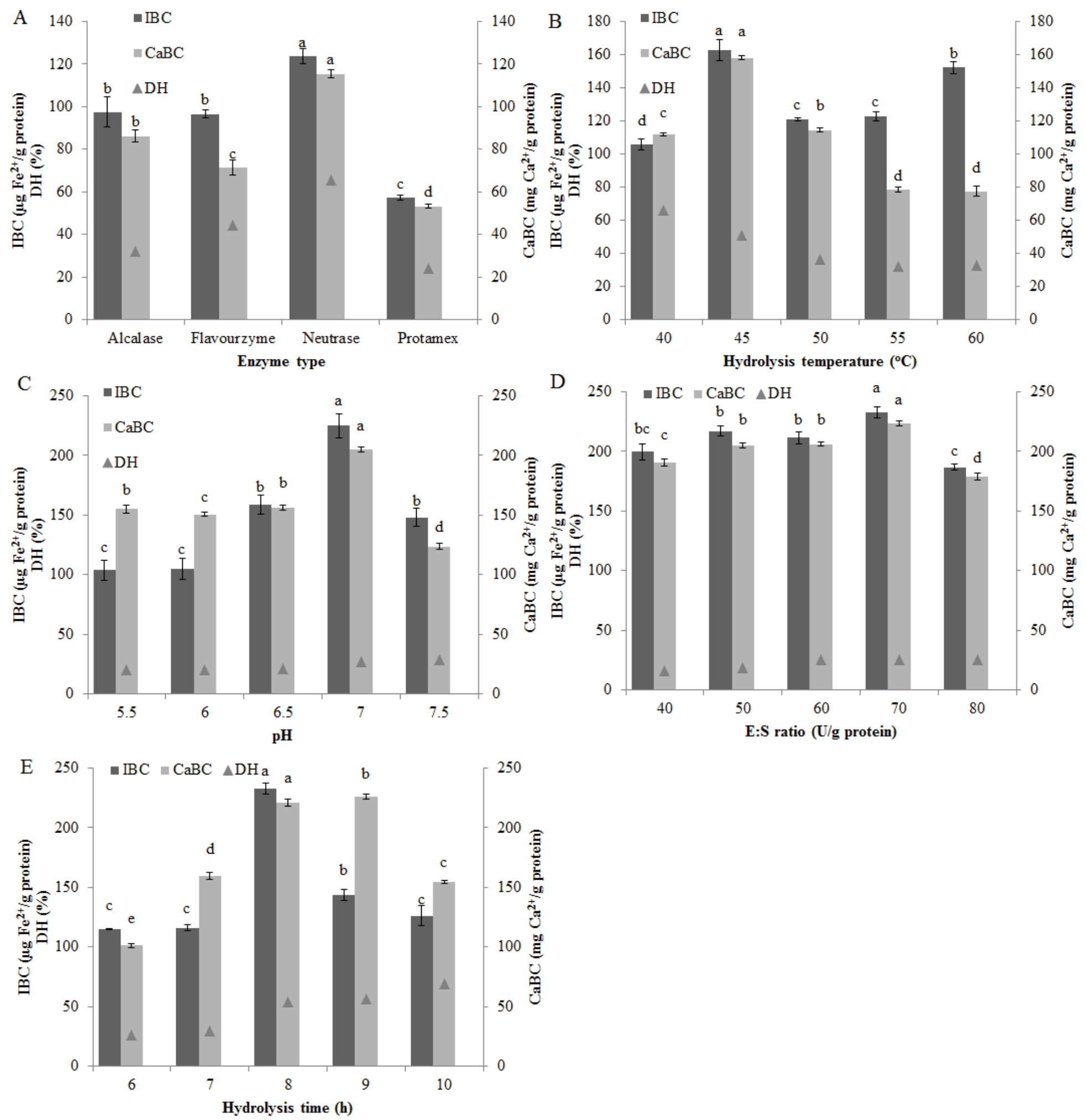

Figure 1

Effect of enzyme type (A), temperature (B), $\mathrm{pH}(\mathrm{C}), \mathrm{E}: \mathrm{S}$ ratio (D) and hydrolysis time (E) on CaBC, IBC and $\mathrm{DH}$ of the proteolysate. The same color bars with different letters indicate significant differences $(p<0.05)$ 

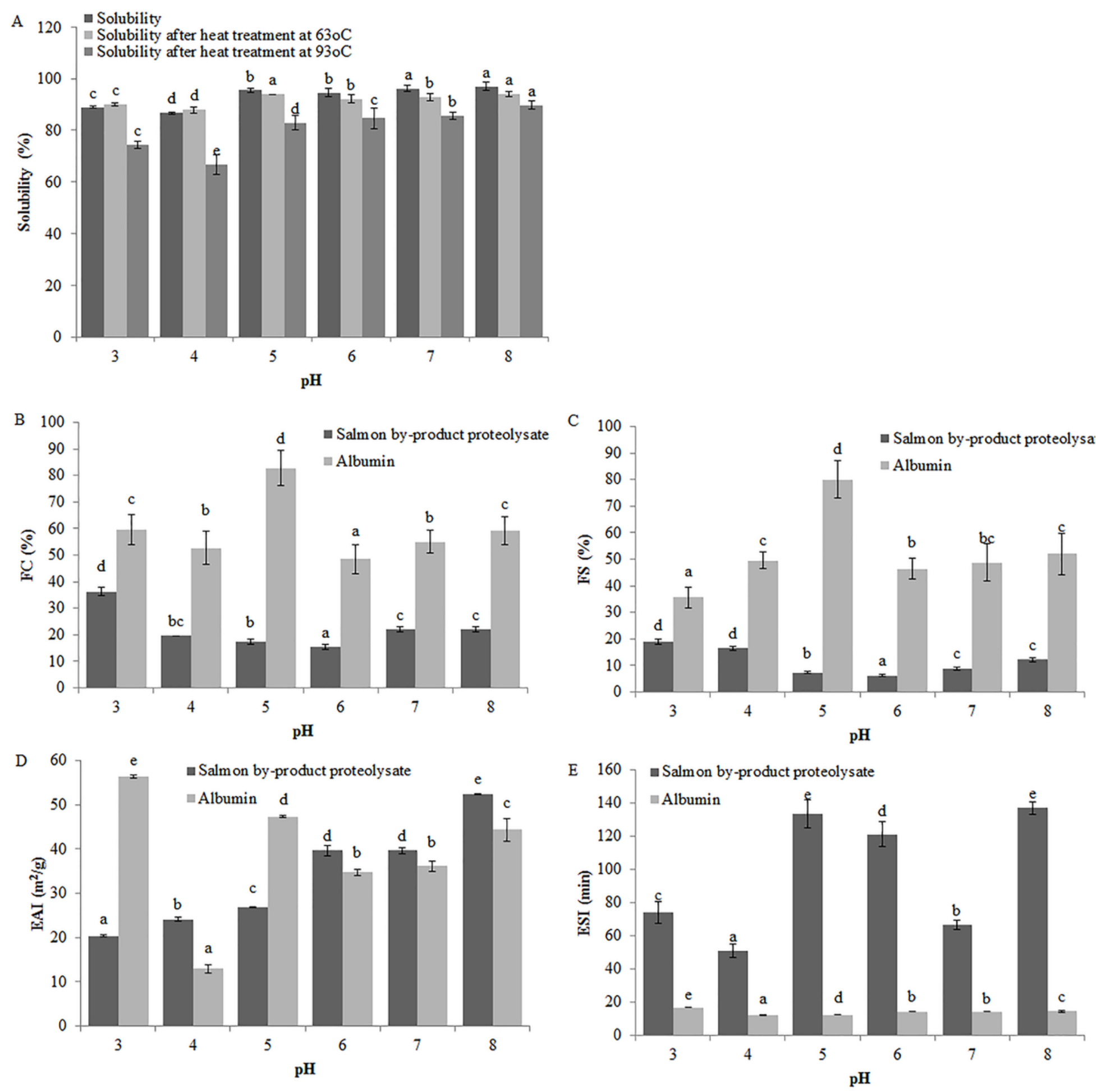

Figure 2

Solubility and heat stability ( $A$ ), foaming property (B and $C$ ) and emulsifying property ( $D$ and $E$ ) of salmon by-product proteolysate. The same color bars with different letters indicate significant differences $(p<0.05)$ 

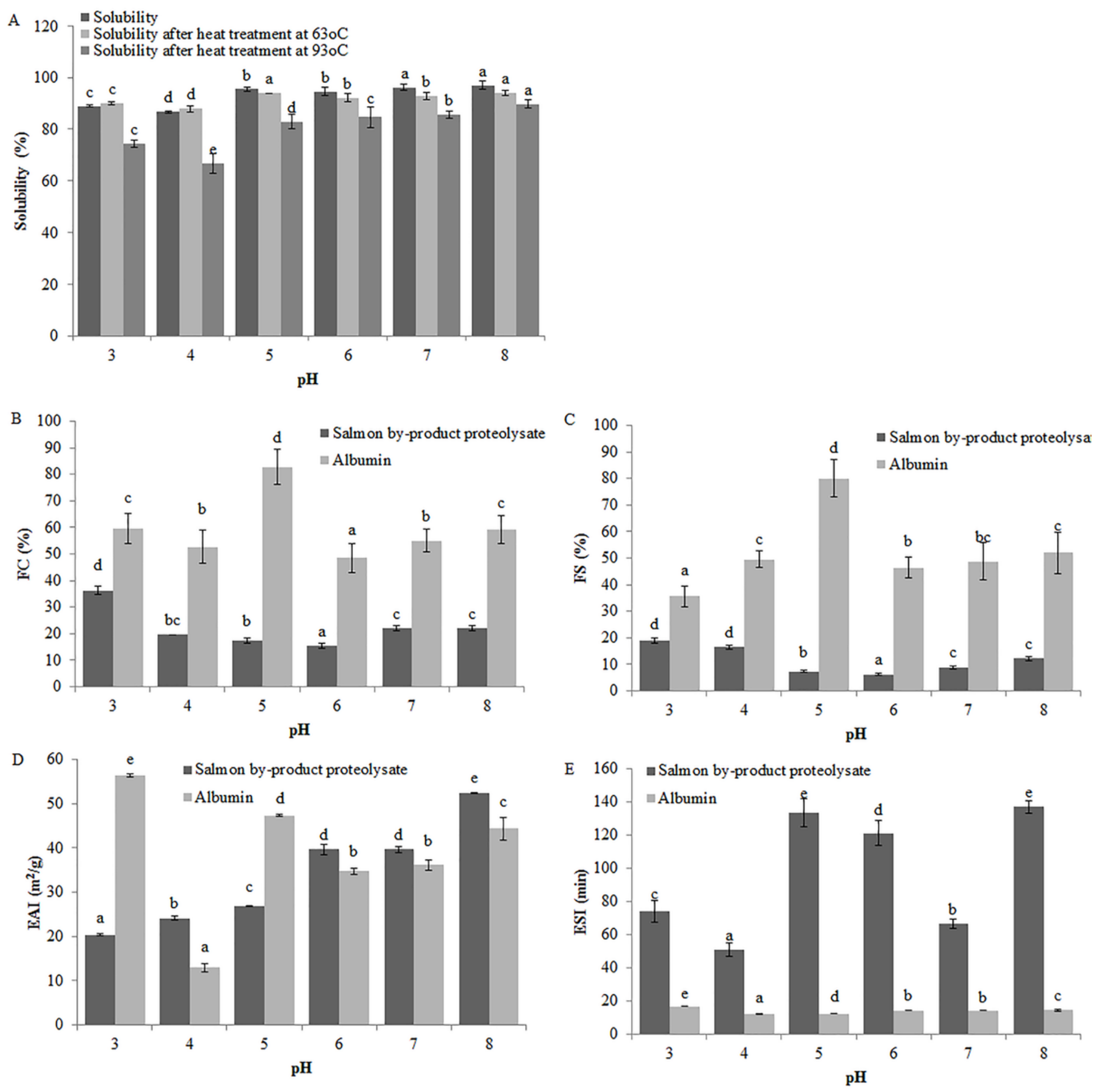

Figure 2

Solubility and heat stability ( $A$ ), foaming property ( $B$ and $C$ ) and emulsifying property ( $D$ and $E$ ) of salmon by-product proteolysate. The same color bars with different letters indicate significant differences $(p<0.05)$ 


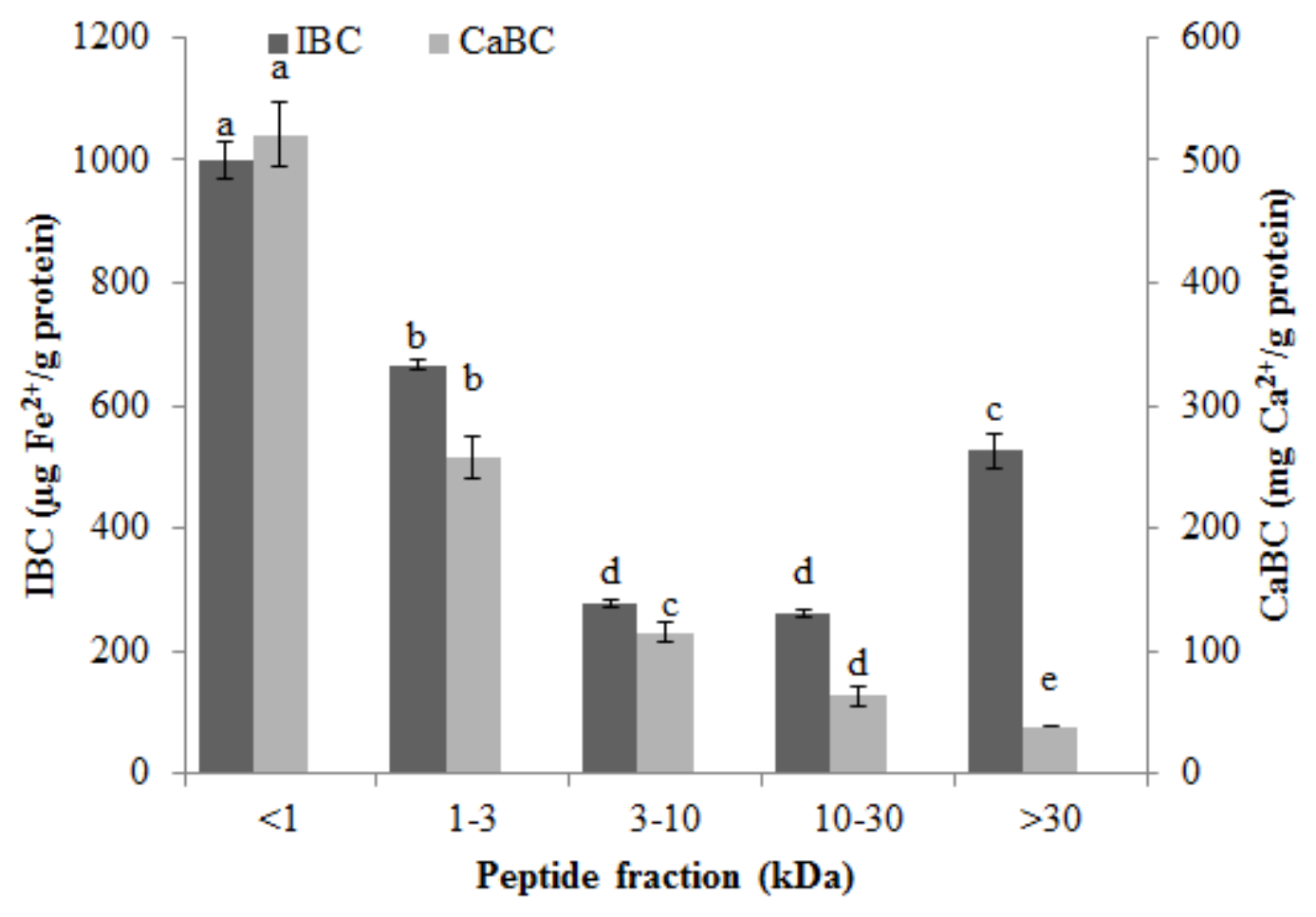

Figure 3

$\mathrm{CaBC}$ and IBC of peptide fractions. The same color bars with different letters indicate significant differences $(p<0.05)$

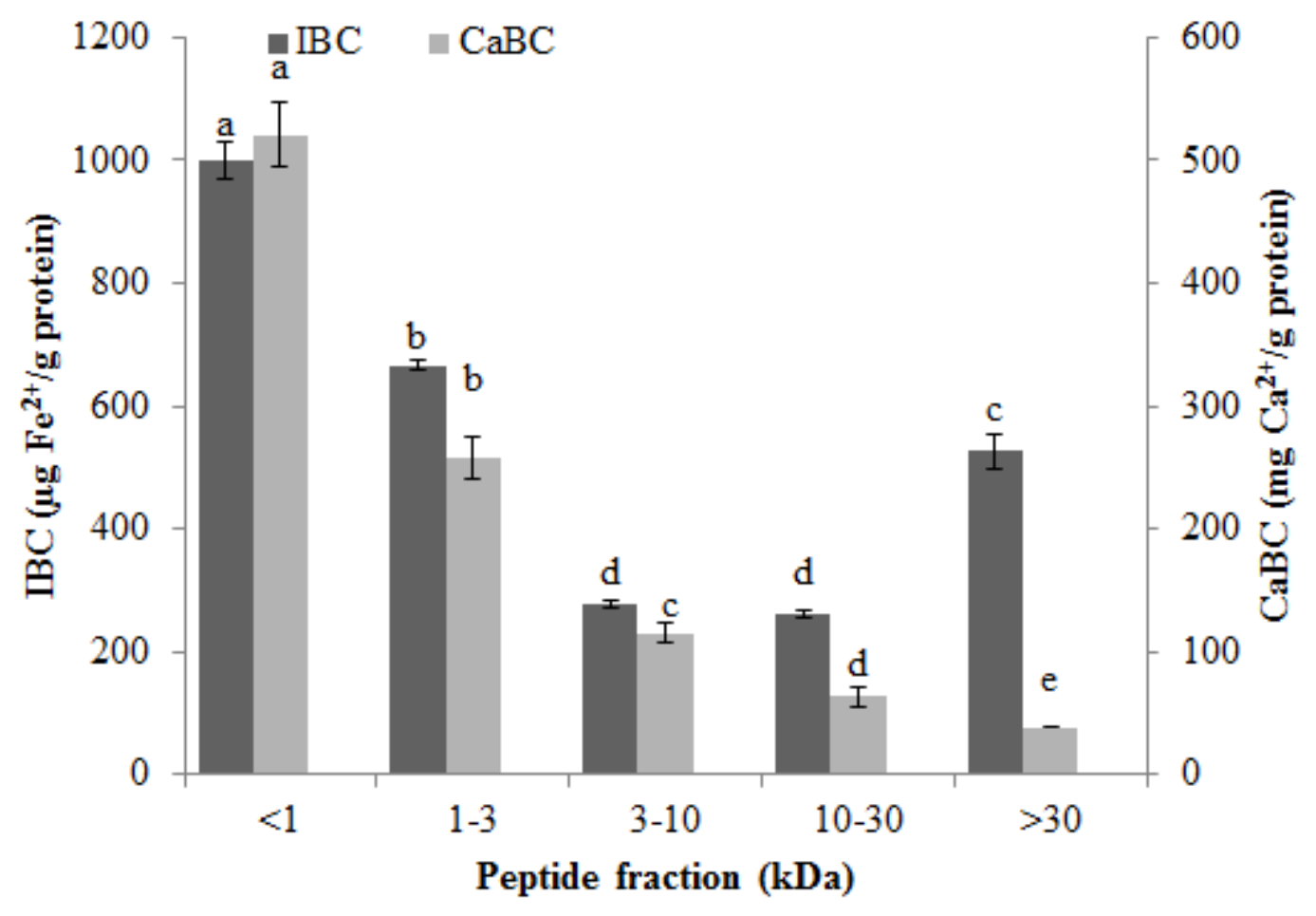

Figure 3

$\mathrm{CaBC}$ and IBC of peptide fractions. The same color bars with different letters indicate significant differences $(p<0.05)$ 


\section{Supplementary Files}

This is a list of supplementary files associated with this preprint. Click to download.

- graphicalabstract.jpg

- graphicalabstract.jpg 